\title{
Knowledge and Power in the São Francisco River Basin Committee
}

\author{
Antenor de Oliveira Aguiar Netto' \\ Patricia Rosalba Salvador Moura Costa ${ }^{2}$ \\ Hannah Uruga Oliveira ${ }^{3}$
}

\begin{abstract}
This article aims to analyze the speeches that constitute the records relating to plenary meetings of River Basin Commission of the São Francisco River (CBHSF), centered on the timeframe of December 2002 to December 2007. Methods insert in documentary sources of analysis relying theoretically the concept of a historically marked document and revealing power-knowledge relations (FOUCAULT, 2009). As a result, we point out that the installation of the basin Committee is configured as a space knowledge and power, in which the members elected, when it has the technical and educational domain, now have an important role in decisions involving the waters of this important river.
\end{abstract}

Keywords: Water resources management, transposition, São Francisco river.

\footnotetext{
1 Professor Doutor Associado do Departamento de Engenharia Agronômica da Universidade Federal de Sergipe-UFS e Pós-doutor em Engenharia Ambiental. Atualmente é professor do Programa de Mestrado e Doutorado em Desenvolvimento e Meio Ambiente da UFS e bolsista de produtividade do Conselho Nacional de Desenvolvimento Científico eTecnológico-CNPq. Email: antenor.ufs@gmail.com

2 Doutora em Ciências Humanas pela Universidade Federal de Santa Catarina. Atualmente é professora de Sociologia do Instituto Federal de Educação, Ciência e Tecnologia de Sergipe-IFS. Também, atua no Programa de Mestrado em Antropologia da Universidade Federal de Sergipe-UFS. Email: patriciarosalba@gmail.com.

3 Graduanda em Engenharia Civil do Instituto Federal de Educação, Ciência e Tecnologia de Sergipe-IFS. Email: hannaholiv@gmail.com.
} 


\section{Conhecimento e Poder no Comitê da Bacia Hidrográfica do Rio São Francisco}

\section{Conocimiento y Poder en la Comité de la Cuenca Del Rio San Francisco}

\section{Resumo}

O presente artigo objetiva analisar as atas das reuniões plenárias do Comitê da Bacia Hidrográfica do Rio São Francisco (CBHSF), centradas no marco temporal de dezembro de 2002 a dezembro de 2007. A metodologia insere-se na análise de fontes documentais apoiando-se teoricamente no conceito de documento como historicamente marcado e revelador de relações de poder e saber (FOUCAULT, 2009). Como resultados, apontamos que a instalação do Comitê da bacia se configurou como um espaço saber e poder, no qual os membros eleitos/as, quando detém o domínio técnico e educacional, passam a ter um papel importante nas decisões que envolvem as águas deste importante rio.

Palavras-chave: Gestão de recursos hídricos, transposição, rio São Francisco.

\section{Resumen}

Este artículo tiene como objetivo examinar las actas de las sesiones plenárias del Comité de cuenca del río São Francisco, centrada em el plazo de diciembre 2002 a diciembre 2007. La metodologia es parte de la análisis de las fuentes documentales con base teóricas en el concepto de documento como históricamente marcada y revelador de las relaciones de poder y saber (FOUCAULT, 2009). Como resultado de este artículo, señalamos que la instalación del Comité se configura como un espacio del conocimiento y el poder, en que los miembros elegidos, cuando se tiene el dominio técnico y educativo, participan activamente de las decisiones relacionadas con el agua neste importante río do Brasil.

Palabras clave: Gestión de recursos hídricos, transposición, Río São Francisco 


\section{Introduction}

This article aims to analyze the speeches that constitute the records relating to plenary meetings of River Basin Commission of the São Francisco River (CBHSF), legally established in June 2001, the possession of members occurring in December 2002. This space power can be configured as parliament of the waters which are deliberate relevant issues to management of the São Francisco River, an important river to Brazilian society. This analysis exposes the dynamics of the issues raised at meetings besides highlighting the power relations of participation of people, social groups and institutions directly involved with the problem of water resources and the environment in Brazil.

Likewise, the study of these documents reveals that the debate on the use of water is established as an important focus that marks modern societies, characterized by technological, scientific, economic, cultural and political development and consequently by harmful impact of humans beings on the natural environment. According to Giddens $(2005,2010)$ the public interest in the environment and its natural resources led democratic societies to the formation of social movements, political parties, non-governmental organizations and management committees in order to carry out actions to protect the environment of the planet earth.

The river basin committees in Brazil were created from the early 1990s by federal and state governance, in the context of the new political and institutional organization of water management, are represented as deliberative arenas, have formalized power, been participating public members, private sector and civil society (ROSS and DEL PRETTE, 1998; MAGRINI and SANTOS, 2001; ABERS and KECK, 2004; ABERS and JORGE, 2008; PORTO et al., 2008).

The São Francisco River is the largest river of Brazil, which has its source and flows into national land, with $639.219 \mathrm{~km}^{2}$, covering a population of 13 million inhabitants, is considered strategic for the development of Brazil since their "waters are used for multiple purposes, es- pecially for electricity generation" (MANETA et al., 2009, p. 1199). Since its foundation the CBHSF has been a space in which there is involvement of civil society, the State and its users deliberating on problems affecting the river and the population that makes use of its waters. During this period, various subjects were put on recorded and presented as guideline such as transposition and revitalization of the river, the drought affecting the population, the generation of electricity, water flow, dams and consequences caused society due to the use of modern techniques without particular care with the waters and communities, especially the riverside.

Therefore, this article is a discussion of key issues officially recording of minutes for plenary meetings that were made available for public consultation through the website of $\mathrm{CBHSF}^{1}$. Whereas the study of water resources management is presented on an urgent basis for understanding how contemporary society deals with problems involving the use of water and environmental issues, it can be said that the analysis of the minutes of the Basin Committee of São Francisco River, among other issues, furthers our understanding of perceptions of power relations and member participation in the deliberations of main issues of the meeting agendas that were officially registered. Therefore, this study contributes to the understanding of how the representation of different sectors of society were recorded in the committee meetings, in addition, it is possible to apprehend the way in which it established the structure of the meetings, their struggles, conflicts and political dissent that governed decisions taken in relation to the management of important natural resource.

\section{The São Francisco river basin: spatial dimen- sions and paths methodological}

The São Francisco River Basin is of fundamental importance to Brazil, which has contributed to the economic development of the area drained by the river. The basin of San Francisco river covers $639.219 \mathrm{~km}^{2}$ drainage area (7.5\% of the country) and average flow rate of $2.850 \mathrm{~m} / \mathrm{s}$ ( $2 \%$ of the country). The river reach $2.700 \mathrm{~km}$ long and rises in Serra da Canastra in Minas Gerais, flowing from 
south to north through the States of Bahia and Pernambuco, where it changes its course to the east, reaching the Atlantic Ocean through the border of the States of Alagoas and Sergipe. The basin encompasses seven Federative Units - Bahia (48.2\%), Minas Gerais (36.8\%), Pernambuco (10.9\%), Alagoas (2.2\%), Sergipe (1.2\%), Goiás $(0.5 \%)$, and the Federal District (0.2\%) - and 504 municipalities, about $9 \%$ of all municipalities in the country (BRAZIL, 2015).

The São Francisco River cross the Brazil from Southeast to Northeast, reasons in which it is popularly called the "river of national integration." Your course can be divided into four distinct sections of physiography (Figure 1): the upper São Francisco; the average San Francisco; the sub-middle São Francisco; and the lower San Francisco (FRANÇA et al., 2007).

Figure 1 - Representation of physiographic regions of the São Francisco River.

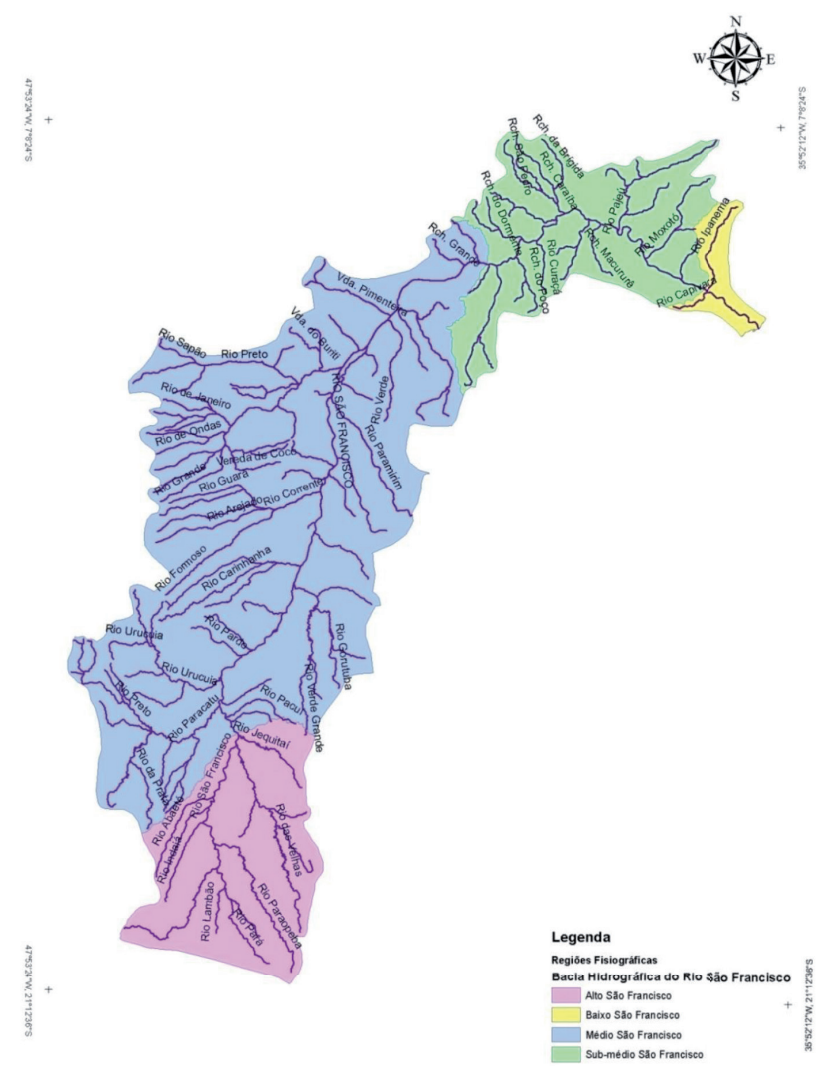

Source: AGUIAR NETTO, 2015.

To construct this article 14 minutes referring to the plenary meetings were researched and analyzed - common (ten meetings) and extraordinary (four meetings) - of the CBHSF between the years 2002 and 2007. The timeframe is justified because in 2002 there was the institutionalization of the committee and in 2007, according to Pessoa (2011) all judgments on the transposition of the waters of San Francisco were gathered at the Supreme Court.

Appraisal of the records is embodied in the method of document analysis, and theoretically based on authors like (LeGoff, 1995) and (Foucault, 2009). For these authors, the discourses that constitute the documents are constructed from the power relations that are established between subjects. The power, in turn, must be understood from the multiple correlations of immanent force, is everywhere, not because it embraces everything, but because it comes from everywhere. In this sense, the documents are of fundamental importance for understanding the social and power relations that are established in different historical times providing an interdisciplinary debate between different fields of knowledge and political.

\section{São Francisco river: the institutionalization of debate and deliberations on its waters}

Several authors reported the new legal and temporal framework of Brazil, by using watersheds as basic units for monitoring and planning water resources, in compliance with Federal Law No 9433 of 01/08/97. From this premise the Union and the Brazilian states began the process of administrative decentralization of water, establishing the Committees. Thus the CBHSF was created by presidential decree of June 5, 2001:

A broad process of social mobilization in the region of São Francisco preceded the publication of the creation decree of the CBHSF, which was coordinated by IMAN with technical support of the ANA and the governing bodies of the states with territory in the basin. This process aimed to involve the public power in its three spheres of action, the main users of water and organized civil entities, accounting in all about 6,000 people (MASCARENHAS, 2009, p. 43). 
The general structure of CBHSF can be seen in Figure 2, with the Plenary as the highest entities, which meets twice a year in ordinary sections, and extraordinary as its members deem necessary. The records, source of this study, are the results of these plenary meetings that bring together all members and alternates representing the four physiographic sections of São Francisco. Because of the large territory of the river basin advisory chambers were created, by region, which enable a collegiate management and more emphasis to local problems.

The CBHSF features a total of 62 (sixty two) elected members, divided into three categories, the public power, water users, civil society,

The final composition, for follow-up, $40 \%$ vacancy for users, 34\% for the public power and $26 \%$ for civil society. The breakdown by state allocated 19 vacancies for Minas Gerais, 12 for Bahia, 8 for Pernambuco, 6 to Alagoas, 6 to Sergipe and 1 to Goiás, plus 5 for the Union, one for the Federal District, one for indigenous communities and one to hidroletricidade (OPARÁ, 2011, p.62-63).

The minutes relating to the possession of the first members and installation of CBHSF occurred in 2002 in Brasilia reveals the power relations that began to be established between the members and alternates and the various institutions, highlighting the importance that the Committee has to have on the national scene. Various social actors representing the Brazilian state and civil society attended the event sealed the importance and contributions to the new parliament conferred the waters of São Francisco for the management of water resources in the country According to the records of minutes of the meeting possession counted by 51 members and 19 alternates, according to Tabel 1.

Tabel 1 - Elected members of the Watershed Committee of São Francisco, according to the categories.

\begin{tabular}{|l|c|c|c|c|c|c|}
\hline $\begin{array}{c}\text { Repre- } \\
\text { sentative- } \\
\text { ness }\end{array}$ & \multicolumn{2}{|c|}{$\begin{array}{c}\text { Representatives } \\
\text { of Members }\end{array}$} & \multicolumn{2}{|c|}{$\begin{array}{c}\text { Representatives of } \\
\text { Civil Entities }\end{array}$} & \multicolumn{2}{|c|}{$\begin{array}{r}\text { Representatives of } \\
\text { the Public }\end{array}$} \\
\hline & Holder & Alternate & Holder & Alternate & Holder & Alternate \\
\hline $\begin{array}{l}\text { Minas } \\
\text { Gerais }\end{array}$ & 10 & 05 & 04 & 05 & 05 & 01 \\
\hline Bahia & 06 & 02 & 02 & 01 & 03 & - \\
\hline $\begin{array}{l}\text { Pernam- } \\
\text { buco }\end{array}$ & 03 & - & 03 & - & 02 & - \\
\hline Sergipe & 02 & - & 01 & 02 & 01 & 02 \\
\hline Alagoas & 02 & - & 02 & - & 01 & - \\
\hline $\begin{array}{l}\text { Distrito } \\
\text { Federal }\end{array}$ & - & - & - & - & 03 & 01 \\
\hline Goiás & - & - & - & - & 01 & - \\
\hline Total & 23 & 07 & 12 & 08 & 16 & 04 \\
\hline
\end{tabular}

Source: Data taken from minutes of office meeting (December 2002)

Figure 2 - General structure of the committee of the watershed of the São Francisco River.

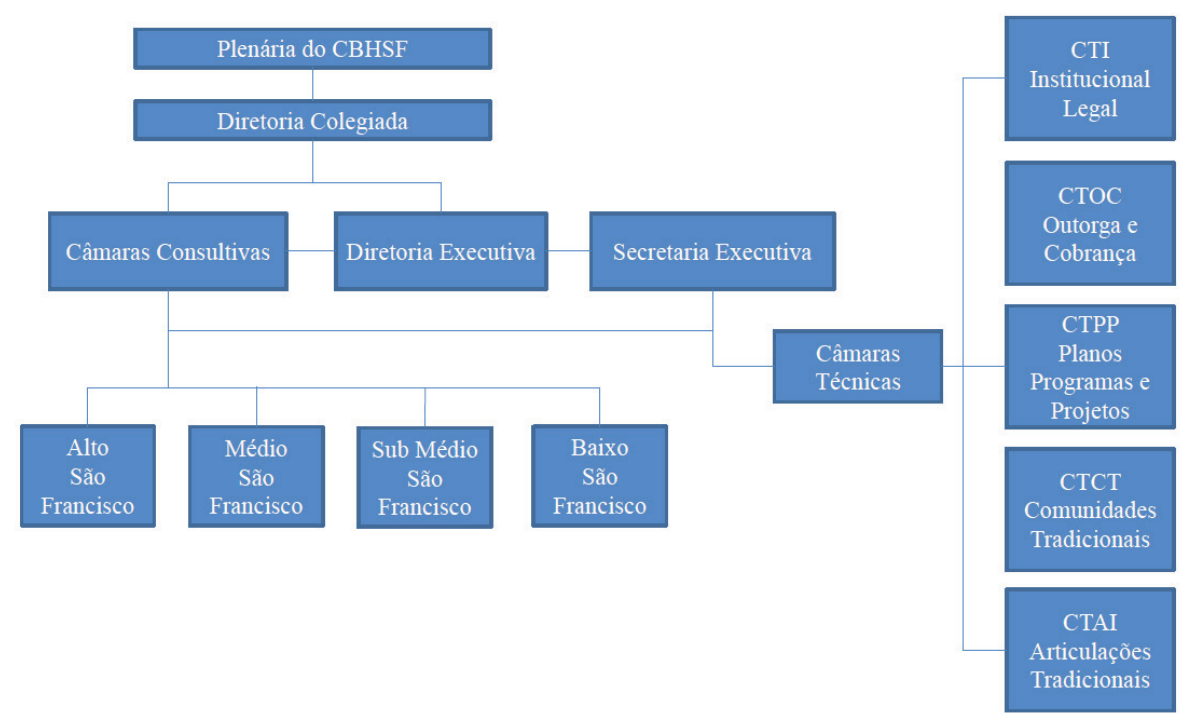


The states of Minas Gerais and Bahia had greater representation, followed by others states as Pernambuco, Sergipe, Alagoas, the Federal District and Goiás, as shown in Table 1. The National Water Agency was responsible for conducting this first meeting where participated institutions of public and private power. The major political influence of the states of Minas Gerais and Bahia is justified by largest land area and their population, plus the greater political and administrative power in the national scene.

The event which concretized the installation and investiture of the members of the committee took place on December 12th and 13th, and had intense debates about the role of the Committee. The opening meeting was performed by a director of the ANA. The representative highlighted the importance of the event, and of the River Basin of São Francisco for the country. The speech of the speaker emphasized the power and responsibilities of the Committee members to act with awareness of the limitations and standards that focus on public administration. It was also stated that the Committee is the foundation of the whole structure of water resources management and is the only and the last instance, bound, however, to the National Water Resources Council, according to the record of their participation:

The Basin Committee is a deliberative forum that manages and decided about water resources, formed by representatives of the segments of the government, users and civil society. The Committees are unique examples in Brazilian public administration of a collective body formed by a majority of representatives who are not from the government, with power to decide matters which conditions, limits and restricts even the most classic and traditional government functions, such as police power and fixing the private collection of values, ie charging for the use of water resources. (Minutes from CBHSF meeting, December 2002, p. 1-2).

The main point of the first day of the meeting was to choose the member who would receive "directly from the President of the Republic, Fernando Henrique Cardoso, the term of office on behalf of others" (Minutes from CBHSF meeting, December 2002). To be chosen or elected by peers, and receive directly from the President of the
Republic the document that records the inauguration of the first members of the committee representing the personification of political capital, as emphasized by Bourdieu (2009). As a result,the representative of Indigenous Communities representing the Truká People community located in the State of Pernambuco was elected with 29 votes. This member acquired the power of representativeness of all to the head chief of the largest Brazilian State.

On December 13th there was an induction which was opened by the head-director of the ANA, which evidenced the strength that this institution had in the beginning of the work of the Committee. All member received their induction document individually. The speech of one of the representatives from the State of Pernambuco is quite revealing about the importance of the Committee and the participation of civil society in the processes of deliberation of the waters of the river:

\begin{abstract}
He commented on the importance of the event that from now on allows the participation of society in planning of the São Francisco basin, he also commented that expectations are high for all segments and for the population regarding the preservation and the economic and social development of the São Francisco basin. He said that the role of the Committee is to administer rationally and with competence the concordance between the various sectors with interest in the basin (MINUTES from CBHSF induction meeting, December 2002, p . 7).
\end{abstract}

This time the meeting was closed with a speech by the director of the ANA that greeted the break of protocol and highlighted the importance of this historic moment, where reason and emotion is blended. He did not fail to underline the importance that the then «President has devoted to the issue of water resources and, in particular, the participatory management of the same» (MINUTES from CBHSF induction meeting, December $2002, p$. 7). Then, there was the official delivery of the induction term to the indigenous representative chosen by pairs, this time the meeting was held at the Planalto Palace. This time the President of the Republic, Vice-President, Minister for the Environment, the Director of ANA and representative of the Casa Civil were present. 
The installation of the São Francisco Committee shows that despite the Brazilian legislation recommending administrative decentralization and encouraging the participation of civil society, as recorded by various researchers (ROSS and DEL PRETTE, 1998; MAGRINI and SANTOS, 2001; ABERS and KECK, 2004; ABERS and JORGE, 2008; PORTO et al. , 2008), the government acted as a centralizing force, by means of its regulatory agency, a fact that was also discussed by VEIGA and MAGRINI (2013).

It seems that a new cycle is started for the São Francisco River, but did the Committee really get the power to decide on the future of the river that is so important for Brazil?

\section{São Francisco: the consolidation of the debates in the collegiate}

After the induction of the Committee members, the discussions on the waters of this river effectively began. From that moment on, the Federal Government established the initial point for the decisions. There were 14 ordinary and extraordinary meetings, excluding the induction meeting. Table 2 indicates the date and the place where the meetings occurred:

Table 2 - Locations and dates of Plenary Meetings.

\begin{tabular}{|c|c|c|}
\hline Meetings & Location & Date \\
\hline Ordinary & $\begin{array}{l}\text { Brasilia } \\
\text { Sao Roque de }\end{array}$ & 12 And 13 December 2002 \\
\hline Ordinary & $\begin{array}{l}\text { Minas Gerais } \\
- \text { - MG }\end{array}$ & May 11, 2003 \\
\hline Ordinary & Penedo- AL & $\begin{array}{l}\text { October } 01-04,2003 \\
\text { (Two minutes - opening Ceremony } \\
\text { and the ordinary meeting ). }\end{array}$ \\
\hline Ordinary & Juazeiro - BA & $\begin{array}{l}\text { July } 28-30,2004 \\
26 \text { And } 27 \text { October } 2004\end{array}$ \\
\hline Extraordinary & Salvador - BA & $\begin{array}{l}\text { (2 Minutes A day - } 27 \text { in Salvador } \\
\text { and another day } 26 \text { and } 27 \text { location } \\
\text { not defined) }\end{array}$ \\
\hline Ordinary & Pirapora- MG & June 16, 2005 \\
\hline Ordinary & Pirapora- MG & June 17, 2005 \\
\hline Ordinary & Recife - PE & December 08, 2005 \\
\hline Ordinary & Aracaju - If & July 12-14, 2006 \\
\hline Extraordina- & Belo Horizonte & December 06, 2006 (Extraordinary) \\
\hline ry/Ordinary & - MG & and december 07, 2006 (ordinary) \\
\hline Extraordinary & Salvador-Bahia & April 11, 2007 \\
\hline Extraordinary & Piranhas - AL & August 08, 2007 \\
\hline Ordinary & $\begin{array}{l}\text { Atogados da } \\
\text { Ingazeira - PE }\end{array}$ & December 10-12, 2007 \\
\hline
\end{tabular}

Source: Data taken from the minutes analyzed.

Since then various matters were in tariffs of the meetings that followed. The first ordinary meeting of the
CBHSF, after the induction, occurred in the city of São Roque-MG. The themes discussed and recorded in this meeting addressed decisions around the Election and inauguration of the first Executive Board of the CBHSF, the indication of members that comprised the Technical Chamber of Institutional and Legal Committee was also approved.

This minute registers an important moment: the election of the executive board, and consequently the first president. Two panels were running for the presidency. The composition of the winning panel initially shows higher concentration of force and power between the regions of High São Francisco and the Middle São Francisco, as the elected vice-president- said, "he would highlight the geographic role of Bahia to be the link between Minas Gerais, in the High São Francisco and the Low São Francisco" (MINUTES from the CBHSF meeting, May 2003, p. 7).

The second deliberative meeting after the election and inauguration of the first board of the CBHSF, occurred between October 1st and 4th, 2003 in the city of Penedo municipality of Alagoas, at this time, the recognition of political capital acquired by the Committee was recorded in minutes,

\footnotetext{
The meeting, already victorious, politically attracted the attention of several areasstarting with several governors of our States of the São Francisco Basin that are going to be present next Friday, parliamentarians, the scientific community, workers and, finally, the Plenary Session of the Committee of São Francisco has undoubtedly become a political fact and this is very important, the country needed to learn that the Committee is in full operation (Coordinator of Consultative Chamber of Low São Francisco. MINUTE, CBHSF opening ceremony, October 01, 2003, p. 2).
}

Important Facts recorded in CBHSF official minutes begin to emphasize the importance of the issues that involve the discussions of the meetings. One record is worthy of attention, the speech of the CBHSF president marks the positions of the new direction, and articulation that 
they would have with the federal government in the decisions of the Committee:

Informed the intention of the CBHSF to always work integrated with the Federal Government on issues related to the management of the water from the São Francisco River (...) It was clarified that the CBHSF role was to discuss granting and allocation of water, without extrapolating its competences. The transposition becoming a bias in this discussion process (MINUTES from CBHSF meeting, October 1st to 4th, 2003, p. 4).

Other issues such as the structure presentation and the approving of the Plano Decenal da Bacia, preservation of the water at the river well and mouth, outflow and highlighting the importance of the representativeness of Committee members, as it dealt with the management of a large watershed they were present during the Minute debates, but the preoccupation with the transposition intensely emerged on the records, as we mention on the following part from the document entitled Carta de Penedo:

The CBHSF claims that no initiative for the use of the water resources of the São Francisco Watershed for transposition is to be adopted before the approval of the Water Resources Management Plan and that all the projects related to the transposition must be sent to the CBHSF for appreciation and presentation of its decision. (MINUTE of the CBHSF, October 1 st to 4th, 2003, pg.5).

The situation of the river was also emphasized which initiated the debate about the transposition:

During the last 502 years, the São Francisco River has donated life, generated wealth, and generously benefited the country. However, we sadly watch its agony, deadly hurt by decades of neglect, the Velho Chico is tired, its donation has reached its limit of its potential, Brasil is in debt with the São Francisco River, and particularly, with the Lower São Francisco (Plenary Participant, MINUTE, CBHSF meeting opening ceremony, October 1st, 2003, pf. 10).

Today we are back discussing the transposition problem, we know we cannot deny wa- ter for the thirsty, but, we also know that we cannot go thirsty tomorrow, then, we cannot think about development in other regions once again, unless our own region is remembered and compensated (Plenary Participant, MINUTE, meeting opening ceremony, October 1st, 2003, pg.3).

The transposition of the São Francisco River has become a neuralgic topic at the Committee meetings. This debate remained present during various plenary meetings, generating conflicts, political and technical disagreement among the members. On June 28th, 2004, in Juazeiro-BA, the third CBHSF ordinary meeting took place and had the presence of the, at the time, Environment Minister, Marina Silva, besides other authorities representing civil entities, public power and users. During this meeting it was made clear the necessity of approval of the Basin Plan and the confrontation of the debates on the transposition. There were constant disagreements among them, which proved to be a difficult matter to be solved for the decision process, mainly between the government and civil entities. The ANA positioning is what follows:
ANA + States + CBHSF elaborated the minute of the plan to be submitted for deliberation; Great technical content, with representativeness; The Watershed Pact, containing the control spots and grantable outflow, represents an extraordi- nary advance in the country; The São Francisco River, still lacks a emergencial situation, there- fore, we may anticipate to water exhaustion as prevention. (MINUTE from CBHSF meeting, July 28th, 2004, pg.1).

After the speech from ANA representative and other entities, the Minister made the following observations:

During the plan elaboration process, the federal Government compromised on not discussing actions on the basin without the approving of the plan by CBHSF and until the present moment, every promise has been kept. It is now time to discuss the plan. We cannot reduce its wideness only to the issue of the transposition. It is right and adequate to find the necessary time to confront the different interests, representing the transversality conditions (...) The Plan, once 
approved, becomes a pact of the involved society. Donating States and those that have not had the opportunity, such as the São Francisco River basin. The CBHSF has the chance to validate the water laws through ethical and technical answers agreed between the government and the general public. We cannot privilege only the States that are crossed by the São Francisco River. Using a metaphor, she compared the States that were receptors of the transposition project, as the ones that live on bread crumbs (MINUTES from the CBHSF meeting, July 28th, 2004, pg. 3).

The metaphor used by the Minister caused some upsetting, and a mayor representing a town from the lower São Francisco River in the State of Sergipe replied:

He questioned the role of the Committee: advisable or deliberative, referring to ANA President's allocations about the deliberation of grants. As a reply to the Minister, he pointed that who lives on bread crumbs are those people living on the São Francisco River sides. (Mayor, MINUTE from the CBHSF meeting, July 28th, 2004, pg. 3-4).

The debates about the transposition continued during the meetings that occurred in Salvador city in October 2004. Discussions about technical comprehension, social and environmental problems were among the most common topics, as highlighted on a recorded speech by an indigenous representative:

The Federal Government is betraying the indigenous community; He spoke about the need to consult the indigenous people about the installation of projects on their areas; Reported CHESF for studies on the construction of hydro electrical power plans negotiating with town mayors; Threatened to pull down CHESF transmission towers; Talked about the indigenous mobilization to fight against the transposition project; (Representative of civil entity, MINUTE from the CBHSF meeting, October 26th and 27th, 2004, pg. 4).

On the other hand, the government representative points out to the lack of knowledge concerning the transposition project:
He considers that bad information on the Transposition Project lead to certain acts that would certainly be different if there was a better understanding. He said that people that are not experts on the field do not understand about the differentiation of outflows and that there is a lack of understanding. He also added that, those who elaborate the project, can see more clearly, that a canal of 127 is only a little more expensive for a smaller outflow. Only those in the field can understand that (Representative of the Public Power, MINUTE from the CBHSF, October 26th and 27th, 2004, pg. 11).

The project fails on its method, the way it has been conducted, the president announced the transposition before there was a Basin Plan. It did not respect the Committee and the 9.433 Law, the EIAS had not yet been introduced. On the moment, the Desertification Program was being presented, not once the transposition was mentioned. The CNRH has already been summoned, because they know that this Committee will not approve the transposition (Representative of the Public Power, MINUTE from the CBHSF minute, October 26th and 27th, 2004, pg. 3).

The minutes showed the importance that the Committee has on the management of waters from the São Francisco River. Moreover, it exposes the participation and interest of groups that represent civil entities, the public power and users. The Committee is a representative pla$c e$, an arena, on which the debates oscillate between technical and political issues, where different groups may win or lose the struggle and consequently the deliberations during the meetings:

The management of the water must be understood not only as a "technical" issue, but also political, as the solution to most conflicts on how the water should be used involve making decisions about priorities, on which groups may win or lose. Although recognizing the conflicts on how to use the water is inevitable in a context in which clean and abundant water becomes more and more scarce in many areas of Brazil, the "politics" tend to be seen with suspicion concerning what is technical, associated with a game of interests that tend 
to wear out the technical coherence of the decisions (ABERS, 2010, pg. 15)

Another study published by Abers et al. (2010) on inclusion, deliberation and control in the Committees and Consortia of river basins in the space collegiate demonstrates that there are two conditions that are a priority for that occurs the deliberations, "the inequality of power may not undermine the process of debate, and each one of the members must agree that the discussion or debate about the best alternatives should be the basis for decision-making" (ABERS et al, 2010, p.228). however, the authors came to the conclusion that there is a widely perceived on the existence of inequalities in organisms that affect the democratic decisions. The lack of technical knowledge has emerged in the research as one of the main problems that hinder the democratic process, then the inequalities of political and economic power.

In 2005 three minutes referring to regular meetings were recorded. Two of these documents were prepared from the meetings that occurred in the city of Pirapora -MG, June 16th and 17th. In these proceedings it is possible to perceive the lack of harmony between the Committee and the public power, especially in relation to the issues of the transposition of the river. The records show the relations of strength and power that have been fought in the Committee, especially, distinct positions between civil society and government in decisions and debate about the transposition, it was also noticeable the dissatisfaction with some of the decisions taken by the governmental agencies that did not consider the legitimate function of the Committee, as participatory and deliberative arena created to manage the basin of São Francisco, according to positioning of a board member of the CBHSF:

It stressed that the competence of the CBHSF and its role in the management of water resources in the basin have been put to the test; It recalled that soon after the meeting in Salvador, they were surprised by the confirmation that the CNRH would deliberate on the project of Transposition of San Francisco. It said that the $\mathrm{CNRH}$ approved the project of transposition contradicting the Plan, and that the Council not even considered the existence of the extremely severe fact, which put in risk the Plan and the National System of Water Resources Management itself - SINGERH; It said that the Committee, while contradicted by its own Ministry of Environment-MMA and $\mathrm{CNRH}$, had its role weakened compared to the other decisions that would have to be taken in relation to the basin of the San Francisco River. (MINUTES from the CBHSF, June 16, 2005, p.1)

The minutes on the meeting of June 17th records the election of second CBHSF directorship, biennium 20052007. A single panel was applied composed, the candidates were elected for unanimity.

In the years 2005-2007, the roles have reversed in a combination between representatives of Minas Gerais and Bahia, in the executive board was elected, representative of low São Francisco. The speech of one of the members of the executive board was recorded searching harmony between government and Committee on the transposition:

It was confirmed that the relationship of the Committee with the government would be close and transparent, discussing the enrollment and the issue relating to the granting, as well as establishment of arrangements; it insisted on the issue of continuity of work in relation to the transposition; It believed in misinformation of the President of the Republic about the project of transposition and knew not the because of its isolation before the discussions of the project (MINUTES from CBHSF meeting, June 17th 2005, p. 3).

One of the representatives of the new directors in the region of low São Francisco, was even emphatic and critical with regard to the role, function and place occupied by the Committee in decisions regarding the waters of the river:

He said that there was a lacked of courage from the Committee, who preferred to be subservient to the minister who has sought to impose at all cost the project to of São Francisco Basin, 
not taking into consideration its future or the threat of disruption of the pact between the States. He said that they will continue in the fight to prevent the project from moving on; he said that it was a great historical error that was being committed, which put at risk the entire national system (MINUTES from CBHSF meeting, June 17th 2005, p. 3).

On the other hand, the representatives of the high San Francisco seemed to defend positions contrary to those of the region of the low, the record in the minutes highlights these comments:

It spoke of the importance of the federative pact and that the Committee should not have an attitude so defensive in relation to ANA and the Ministry of Integration; registered the need for the creation of the Agency of Basins of the Committee, so that it has administrative autonomy (Representative of Alto, MINUTES from meeting CBHSF, June 17th 2005, p . 7).

The speech of indigenous representative was scored in official document, his statements put into focus the difficulties encountered by this population, as well as the low representativeness of the group in the Committee, in quantitative terms:

He said that it was hard to count with only 01 indigenous representative to disclose the issue of transposition in the States of MG, BA, SE, AL and PE (MINUTES from meeting CBHSF, June 17th, 2005).

In December of 2005 an ordinary meeting occurred in the city of Recife, besides the transposition, it was recorded at minutes the urgent need of the creation of the Agency of Basins to give more autonomy to the Committee, second component of the executive board:

Reinforces the difficulty of acting without the Agency of the Basin, and with limited resources. Emphasizes again the construction of the Basin Agency, during the year of 2006. It is proposed that the Committee approves a motion addressed to the Federal Government to ensure that the resources of the ANA will be substantially increased (MINUTES from CBHSF meeting, December 8th, 2005, p. 3).

The debate on the creation of the agency was deepened in the year of 2006, but before that, remains the conflict between transposition/revitalization of the São Francisco river with distinct positions between government and Committee. This one is against the transposition, generating a conflict between institutions.

The studies performed by ABERS and JORGE (2008, p. 12) show that in the "vast majority of cases, the creation of Committees is associated with the intention to solve practical problems in the basin, such as the worsening of environmental problems, conflicts between uses of water or the occurrence of some critical event". Thus, it was interesting to observe that the centrality of the debates in CBHSF, in its first years of operation, would occur by concrete fact of the transposition of its waters to other regions, with great focus on the environmental damage.

The debate about the transposition of the waters of the São Francisco River for the semi-arid northeastern Brazil surpassed the CBHSF and governmental bodies and became subject matter discussed in the daily lives of the people of the states bordering the waters of this river, from other states, religious organizations and social, as well as the regional and national printed media and television.

In 2006 there was a new election for directors of CBHSF. The Coordinator of the Sub Medium Advisory Chamber presented the proposal of panel, he demanded to record in minutes a dispute by institutional power and the need for multiplication of powers, especially, between representatives of the Member States and regions that make up the committee.

The indigenous representativeness was debated during the last ordinary and extraordinary meetings in December 2006 in the city of Belo Horizonte - MG, with emphasis to the need for the increase in the number of vacancies for these communities. On the other hand, it also was recorded the need for enrollment, regulations and levying 
of the use of water, themes already previously discussed, which have gained space in deliberative meetings of 2007. In April, there was a change in the internal regulations of the CBHSF, the Indigenous Peoples was included in the composition of the CBHSF changing the original redaction to Public Power, Users, Civil Society and Indigenous Peoples, also managed to increase its representation on the Committee, going from one vacancy to two. It also altered the aspects of the rules related to the mandates of the President, Vice-President, Secretary and Coordinators of Regional Consultative Chambers that have become coincident, of three years and may be reelected only once.

There was record that the CBHSF should conduct public hearings for the discussion of matters considered relevant by the Plenary, directly, or through its Regional Advisory Boards, one of the important points of amendment of the rules and that gains prominence in this Article was the assertion that the minutes should be drafted in summary form, approved by the Plenary, signed by the President and by the Secretary and, later, made public, in particular by means of the CBHSF electronic site, moreover, the importance of "do appear in the minutes the discordant point of view, when it deems relevant" (XIII EXTRAORDINARY PLENARY ALTERATION IN the INTERNAL REGULATIONS OF THE CBHSF April 11th, 2007 - Salvador/Ba).

These points of the rules concerning the minutes are important in order to democratize access to the debate and decisions occurred in ordinary and extraordinary meetings of the CBHSF, on the other hand, it makes clear that the conflicting positions should be recorded when they were judged relevant, the question that arises is, to whom it is destined the political capital to judge whether the conflicting positions should be included in a document? With this change in the rules it is explicit the normalization of relations of forces that constitute this important area of decision, probably, as highlighted by ABERS et al (2010) and LEMOS et al (2010), the technical-scientific knowledge, the political and economic capital acquired by members of the Committee confer greater participation in the decision-making process, and thus the decision of which must be registered effectively in official documents of Committees can take these aspects into consideration, and silence representatives of segments with lower quantitative participation, little political expression and technical knowledge, causing an unequal process on the deliberation of the waters of the river, and clouding the record of official documents important for historical analysis.

In August 2007, in the city of Piranha-AL, there was the election for collegiate management 2007-2010, and the only panel ran and won, represented by representative of the Civil Society of the Institute Guaicuy of Minas Gerais, representative of the Government of Bahia and Government representative from Alagoas. After the election, there were the 17th and 18th Plenary meetings of the Committee of the Hydrographic Basin of the Rio São Francisco December 10-12th, 2007 in the municipality of Afogados da Ingazeira- PE. In the minutes, the record of the CBHSF president's statements informs:

On the decision of the Regional Federal Court
that on today's date it granted the prelimi-
nary injunction suspending the works of the
transposition, including the withdrawal of the
army, suspension of the certificate of sustai-
nability of the work by ANA, suspension of
the decision of the CNRH ( ... ) reinforces with
the emphasis on the need to revitalize the
Basin and reaffirmed the positions already
assumed by CBHSF in relation to the transpo-
sition theme (MINUTES from CBHSF meeting,
December 10-12th, 2007, p . 1)

The first meeting with the directors elected for the 20072010 management emphasized the positioning of the Committee against the transposition and drew particular attention to the need of revitalization of the river, word that arose a few times previously. The transposition was the most discussed themein the minutes studied, followed only by the levying of the waters, the creation of the agency of the basin and the election of directors. The lines of these last minutes of 2007, show the disruption of the CBHSF with the government, which the main factor was the project of the transposition of the waters of the São Francisco River. 


\section{Conclusions}

The installation of the committee of the hydrographic basin of the São Francisco River was directly linked to the actions of the federal government. The first directors were elected by direct vote of the elected representatives in deliberative meetings, however they reflected the central power of the Brazilian government, being notorious greater concentration of power in the state of $\mathrm{Mi}$ nas Gerais followed of Bahia.

In the course of the plenary meetings that have marked the conduct of the debate over the waters of São Francisco the theme of transposition has emerged as a central focus, presenting itself at the same time as sociopolitical conflict that has engendered the construction and conduction of this area of decentralized power.

We can infer that the Committee of the installation of the basin of the São Francisco River was configured as a space of knowledge and power. Thus, the elected members, when it has the technical and educational domain, now have an important role in decisions involving the waters of this important river in Brazil.

In all the minutes analyzed it was possible to observe that the debates and deliberations were formed through relationships of strength, especially made between representatives of the government and other members. However, as Foucault (2009) emphasizes, the power is disseminated and it is found on all the parties and on the actions of all segments, therefore, the presence, even if small, of representatives of civil society, such as indigenous and Quilombola communities were significant to cause changes in the rules of the CBHSF and draw attention to the particularities of these traditional populations. It can be inferred that the installation of the watershed Committee is configured as a space of power and knowledge where elected members have an important role in the deliberation of the waters of this important river, the projection and democratization of debates, the organization of deliberative space with the election of members and geographical movement of the encounters in cities bathed by the river, are important points that contributed to the strengthening of the Committee and the maturing of the decisions of the management.

The results also point to the installation and permanence of a space of knowledge and power apparently autonomous, but with various nuances of technical, scientific, political and economic influence in the participation of their members. It was observed that the institutionalization of the CBHSF allowed the construction of collective dialog involving governmental institutions, private and civil society. Activities such as these are important for the development of planned actions with the objective of conservation of water resources, in addition, it creates the possibility of exposure of difficulties encountered by communities who live directly on these waters.

\section{References}

ABER S, R.; KECK, M. Comitês de Bacia no Brasil Uma Abordagem Política no Estudo da Participação Social. R. B. Estudos Urbanos E Regionais, 6 (1), 55-68. doi: 2317-1529, maio, 2004.

ABERS, R.; DINO, K. J. Descentralização da Gestão da Água: Por que oscomitês de bacia estão sendo criados? Ambiente e Sociedade, julho/dezembro, 2008.

ABERS, R. Introdução: Pensando politicamente a gestão da água. In Rebecca Abers (Org), Água e Política: atores, instituições e poder nos organismos colegiados de bacia hidrográfica no Brasil, São Paulo: Annablume, pp. 13-36, 2010.

ATA DA REUNIÃO DE POSSE DO CBHSF- DEZEMBRO DE 2002. Disponível em:<http://cbhsaofrancisco.org.br/download/ ATAS/ANO\%202002/Ata.CBHSF.Posse.13.12.2002.pdf>

ATA DA I REUNIÃO PLÉNARIA DO CBHSF - MAIO DE 2003. Disponível em: <http://cbhsaofrancisco.org.br/download/ATAS/ ANO\%202003/Ata.CBHSF.Plenaria.11.05.2003.pdf>

ATA DA II REUNIÃO PLENÁRIA DO CBHSF - OUTUBRO DE 2003. Disponível em: <http://cbhsaofrancisco.org.br/download/ ATAS/ANO\%202003/Ata.CBHSF.II.Plenaria.01.10.2003.pdf>

ATA DA III REUNIÃO PLENÁRIA DO CBHSF - JULHO DE 2004. Disponível em: <http://cbhsaofrancisco.org.br/download/ATAS/ ANO\%202004/Ata_III_Reuniao_Plenaria_28_a_30.07.2004.pdf>

ATA DA IV REUNIÃO PLENÁRIA DE NATUREZA EXTRAORDINÁRIA DO CBHSF-OUTUBRO DE 2004. Disponível em: <http:// cbhsaofrancisco.org.br/download/ATAS/ANO\%202004/Ata_ IV_Plenaria_26_a_27.10.2004.pdf>

ATA DA V REUNIÃO PLENÁRIA DE NATUREZA EXTRAORDINÁRIA DO CBHSF - OUTUBRO DE 2004. Disponível em: <http:// 
cbhsaofrancisco.org.br/download/ATAS/ANO\%202004/Ata. CBHSF.V.Plenaria.27.10.2004.pdf>

ATA DA VI REUNIÃO PLENÁRIA ORDINÁRIA DO CBHSF - JUNHO DE 2005. Disponível em: <http://cbhsaofrancisco.org.br/download/ATAS/ANO\%202005/Ata.CBHSF.VI.Plenaria.16.06.2005. pdf>

ATA DA VII REUNIÃO PLENÁRIA DO CBHSF - JUNHO DE 2005. Disponível em: <http://cbhsaofrancisco.org.br/download/ ATAS/ANO\%202005/Ata.CBHSF.VII.Plenaria.17.06.2005.pdf>

ATA DA VIII REUNIÃO PLENÁRIA DO CBHSF - DEZEMBRO DE 2005. Disponível em: <http://cbhsaofrancisco.org.br/download/ATAS/ANO\%202005/Ata.CBHSF.VIII.Plenaria.08.12.2005. pdf>

ATA DA IX E X REUNIÕES PLENÁRIAS DO CBHSF - JULHO DE 2006. Disponível em: <http://cbhsaofrancisco.org.br/download/ATAS/Atas-ano-2006/Sintese_Ata_Plenaria_IX_e_X_juIho2006_Final1.pdf>

ATA DA XI REUNIÃO PLENÁRIA ORDINÁRIA/EXTRAORDINÁRIA DO CBHSF - DEZEMBRO DE 2006. Disponível em:<http://cbhsaofrancisco.org.br/download/ATAS/Atas-ano- 2006/Ajuda_Memoria_XI_e_XII_Plenarias_BH_MG.pdf $>$

ATA DA XVII E XVIII PLENÁRIAS DO COMITÊ DA BACIA HIDROGRÁFICA DO RIO SÃO FRANCISCO - DEZEMBRO DE 2007. Disponível em: <http://cbhsaofrancisco.org.br/download/ATAS/ ANO\%202007/Ata.CBHSF.Plenaria.12.12.2007.pdf>

BOURDIEU, P. O poder Simbólico. 12. ed. Rio de Janeiro: Bertrand Brasil, 2009.

BRASIL. Comitê da bacia hidrográfica do rio São Francisco. Disponível em: http://cbhsaofrancisco.org.br/a-bacia/ Acesso em 15 de junho de 2015.

CBHSF. Guardians do São Francisco - Opará. Brasilia, 2011.

FOUCAULT, M. O sujeito e o poder. In: RABINOW, Paul; DREYFUS, Hubert. Michel Foucault. Uma trajetória filosófica. Para além do estruturalismo e da hermenêutica. Rio de Janeiro, Forense Universitária, p. 231-249, 1995.

FOUCAULT, M. A Ordem do Discurso aula Inaugural no College de France, pronunciada em 2 de dezembro de 1970. Rio de Janeiro, Leituras Filosóficas, 2009.

FRANÇA, V. L. A.; CRUZ, M. T. S.; FONTES, A. L. Atlas Escolar de Sergipe histórico e cultural. João Pessoa: GRAFSET. 2006.

GIDDENS, A. Sociologia. 6. ed. Porto Alegre: Artmed, 2005.

GIDDENS, A. A política das Mudanças Climáticas. São Paulo: Jorge Zahar Editora. 2010.

MAGRINI A, SANTOS M. River basin management and the national water resources policy in Brazil. In Brebbia CA, Anag- nostopoulos $\mathrm{P}$, Katsifarakis K, Cheng AH-D (Org) Water resources management. Southampton, v. 4, pp. 79-88, 200.

MANETA, M.P.; TORRES, M.; WALLENDER, W.W.; VOSTI, S.; KIRBY, M.; BASSOI, L.H.; RODRIGUES, L.N. Water demand and flows in the São Francisco River Basin (Brazil) with increased irrigation. Revista Agricultural Water Management,v.96, p. 11911200, 2009.

MASCARENHAS, A. C. O Comitê da Bacia Hidrográfica do Rio São Francisco. Revista do CBHSF, v. 1 pp.42-52, 2009.

PESSOA, M. G. P. A. Proteção, a Bacia Hidrográfica do Rio São Francisco, a ação popular ambiental e a concretização do direito fundamental ao Meio Ambiente equilibrado. In: LUCAS, A. A. T.; NETTO, A. O. A. Águas do São Francisco. São Cristovão, Editora UFS,.p. 127 - 146,2011.

PORTO, M. F. A.; PORTO, R. L. L .Gestão de bacias hidrográficas. Revista Estudos Avançados, São Paulo, 22 (63), 2008.

ROSS, J. L. S.; MARCOS E. P.. “Recursos hídricos e as bacias hidrográficas: âncoras do planejamento e gestão ambiental." Revista do Departamento de Geografia v.12, p.89-121, 1998.

VEIGA, L. B. E.; MAGRINI, A.The Brazilian Water Resources Management Policy: Fifteen Years of Success and Challenges. Water Resour Manage 27, p. 2287-2302, 2013.

Recebido em 18 de junho de 2016.

Aceito em 11 de julho de 2016. 